\title{
Entrepreneurship management skills requirements in an emerging economy: A South African outlook
}

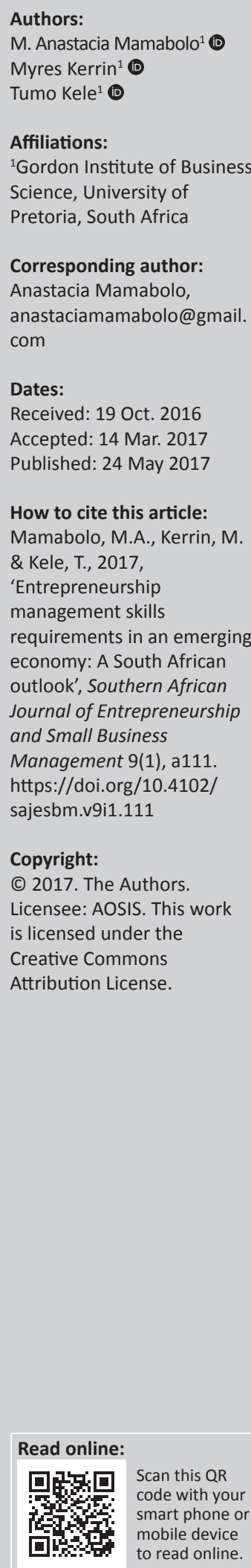

Background: Entrepreneurship is seen as a driver of sustainable economic growth as entrepreneurs create new businesses and employment. Because entrepreneurship contributes to economic growth, it is important to have the skills needed to be successful in business venturing.

Aim: This study's aim was to determine skills required by South African entrepreneurs to run their businesses.

Setting: Entrepreneurs who own and run businesses in South Africa.

Method: A sequential exploratory mixed method research design was applied in the study. Phase I, which consisted of qualitative interviews with 15 entrepreneurs and 6 national experts, resulted in skills that were used to develop a survey instrument. A survey was conducted in Phase II on 235 entrepreneurs to confirm the skills to a larger population.

Results: Confirmatory factor analysis results showed that entrepreneurs require financial management, human resource management, start-up, social and interpersonal, leadership, personality, marketing, technical and business management skills.

Conclusion: The identified skills through empirical research will be instrumental in the training of entrepreneurs and as a tool to measure skills in future entrepreneurship skills research.

\section{Introduction}

Globally, there has been an increasing fascination in understanding entrepreneurs operating in an emerging market context (Bruton, Ahlstrom \& Obloj 2008). Entrepreneurs in emerging markets contend with formal and informal public and private institutions, which can impact the development of entrepreneurship (Ahmad et al. 2010). As a result, the skills that entrepreneurs in this type of context apply to lead their businesses to survival and growth may be distinct from those applied by entrepreneurs in the developed markets (Solesvik 2012). Morales and Marquina (2013) argued that even entrepreneurs from developed countries when compared amongst themselves may have notable differences in skills requirements.

South Africa as one of the developing markets aims to improve the economy and create employment through entrepreneurship (Brière, Tremblay \& Dau 2014). Despite efforts to invest in entrepreneurship, South Africa is challenged by a low entrepreneurial activity and high unemployment rate compared to the other sub-Saharan countries (Herrington \& Kew 2015). The low entrepreneurial activity includes a low percentage of potential and established entrepreneurs. There are also comparatively fewer entrepreneurs who identify opportunities and believe that they have the necessary skills to create business ventures. Some of the challenges encountered include the low levels of entrepreneurial skills that are seen as important elements in economic and entrepreneurship development (Adendorff, Emuze \& Vilakazi 2013).

Research on entrepreneurial skills adopts human capital theory perspective, which states that skills are the outcomes of investment in education and work experience (Becker 1964; Chell 2013; Unger et al. 2011). Additionally, Chell (2013) argued that research on entrepreneurial skills is mainly theoretical, lacking support by empirical evidence. Thus, there is no clarity on the specific skills required by entrepreneurs (Morales \& Marquina 2013). Some of the complications in researching entrepreneurial skills are the lack of an agreed definition and the clarity of construct as it is often interchanged with entrepreneurial competencies (Chell 2013). This highlights that it is important to define and identify skills required by entrepreneurs with the support from empirical research. Therefore, this study will clearly define and separate skills from competencies. 
With regard to the entrepreneurship research in South Africa, there is a research gap on specific entrepreneurial skills suitable for entrepreneurs in this context (Adendorff et al. 2013). As much as studies on skills in entrepreneurship are increasing elsewhere (Deakins, Bensemann \& Battisti 2016; Loué \& Baronet 2012; Shabbir, Shariff \& Shahzad 2016), there is little about entrepreneurial skills required by entrepreneurs in South Africa. Therefore, the aim of this study was to determine the entrepreneurial skills required by entrepreneurs to run their businesses on a day-to-day basis. Entrepreneurial skills are one of the significant contributors to the success and performance of any business venture (Unger et al. 2011).

Entrepreneurs in South Africa require three types of support, namely human, financial and social capital (Brière et al. 2014). With regard to human capital, entrepreneurs would greatly benefit from entrepreneurial skills and training according to their developmental stages and the sector of activity. The lack of entrepreneurial skills may be because of inadequate training (Brière et al. 2014) and a poor educational system as the South African public education system is classified as the worst in the world, far worse even than peer developing countries (Turton \& Herrington 2012). The 'education system has been failing to effectively equip individuals with skills and confidence required to consider entrepreneurship as a valid choice' (Turton \& Herrington 2012:28).

Studies conducted in emerging markets have shown that the significance of entrepreneurship education lies in the positive relationship between the level of education and desire to be entrepreneurial (Herrington, Kew \& Kew 2014). The educational institutions need to provide learners with practical exposure of entrepreneurship as a career path and put a stronger focus on problem solving skills and selfconfidence, which are baseline skills for successful business venturing (Herrington et al. 2014). Individuals with a higher level of education are more likely to have intentions to start new business ventures (Amorós \& Bosma 2014). According to Turton and Herrington (2012) one of the requirements to increase a pool of potential entrepreneurs, individuals with entrepreneurial intentions and early-stage entrepreneurs is an effective education system. However, if the skills needed for successful business venturing are identified and training based on the identified skills is conducted, even in a weaker educational system the feasibility and desirability of entrepreneurs can still be increased.

The results of the study showed that entrepreneurs require financial management, human resource management, start-up, social and interpersonal, leadership, personality, marketing, technical and business management skills. The identified skills through empirical research will be instrumental in the training of entrepreneurs and as a tool to measure skills in future entrepreneurship skills research.

The study presents the reviewed literature that supports the arguments relevant to the academic inquiry. The research methodology is presented, followed by the quantitative findings. The discussions of the findings are argued against the existing literature. The study concludes with the implications for entrepreneurs, training institutions and entrepreneurship scholars.

\section{Literature review}

Chell (2013) lamented that there has been a loss of sight in the definition and function of skill within the field of entrepreneurship. Further, the construct skill is at times confused or interchanged with that of competencies.

\section{Distinguishing skills from competencies}

Competencies are perceived to be equivalent or the same as abilities, skills and knowledge (Chell 2013; Hayton \& McEvoy 2006), which mean that in many instances these constructs are applied interchangeably (Mitchelmore \& Rowley 2010; Smith \& Morse 2005). The lack of a clear distinction in entrepreneurship literature has resulted in many scholars appearing to confuse entrepreneurial skills with entrepreneurial competencies (Chell 2013). Consequently, this has impeded the expansion of the theoretical grounding of skills that can be derived from empirical studies. Not only do these obscure definitions and affect the field of research, but they also retard the possible practical application and implementations of relevant skills training programmes.

Competencies are the fundamental characteristics of an individual, which include motives, traits, skills, ability and knowledge that are essential in starting and running a business venture (Bird 1995; Boyatzis 1982). A different view by Hayton and McEvoy (2006) is that competencies mirror the integration of particular knowledge, skills, abilities and other personality characteristics resulting in productive performance. A recent theoretical article defined entrepreneurial competencies as 'clusters of related knowledge, attitudes and skills which an entrepreneur must acquire to enable him to produce an outstanding performance and maximise profit while managing a business venture' (Lugemwa 2014:76). Therefore, competencies are in the context of this study defined as the ability to perform in a manner that satisfies or surpasses the set performance criteria as a result of the combination or integration of knowledge, skills and other personality characteristics. It follows that entrepreneurial competencies are the entrepreneurial capability to perform entrepreneurial activities above the required standard as a result of the combination entrepreneurial personal attributes, knowledge, skills and personality characteristics.

\section{Defining skills}

A simple definition refers to skill as the ability to perform a task (McLarty \& Dousios 2006). In the entrepreneurship domain, defining and specifying skills is ambiguous and complex (Chell 2013; Morales \& Marquina 2013). The contributions from practitioner's training programmes have 'designed inconsistent entrepreneurial skills lists while 
trait psychology reduced skills to inherent traits' (Morales \& Marquina 2013:129). In research, scholars do not clearly define or re-invent the definition of skills and entrepreneurial skills in the context of their studies (Pyysiäinen et al. 2006). If skills are properly distinguished from and related to the elements in which they are embedded, this will be useful for empirical evaluation and practical implementation (Pyysiäinen et al. 2006) as well as theory development.

In the neoclassical approach, thus using human capital theory, skills are obtained through human capital investments in education and work experience (Becker 1964). Furthermore, human capital theory maintains that skills can be learnt and old ones perfected while training or performing tasks. For skills to be effective they must be applied to the different entrepreneurial tasks (Unger et al. 2011). Therefore, skills according to human capital theory are results of investments in their acquisition, they can improve through training and development and they need to be proficiently performed.

A review of some of the adopted definitions in literature (as seen in Table 1) through the human capital theoretical base indicates that skills in the entrepreneurial context are broadly described as the ability to perform a task. The typically shallow definition frame has tended to narrow the scope of skills to whether a person can do some set of tasks or not. Further, defining skills in this manner does not acknowledge that, for a person to be able to perform a task, there are some investments or sources needed to produce the skill to perform a task. Lastly, that some of skills can be learnt and refined through training and exposure.

Based on the characteristics of the skills aligned with human capital theory as portrayed in Table 1, skills in this context are defined as:

the proficiency in performance of a task, as a result of human capital investments (formal and education, entrepreneurial education, work, industry and entrepreneurship experiences) and can be improved by training, practice and development.

The entrepreneurial skills in this context will be:

the proficiency in performing tasks in the entrepreneurial phases as a result of human capital investments (formal and education, entrepreneurial education, work, industry and entrepreneurship experiences) and can be improved by training, practice and development.

\section{Categories of skills}

Defining skills according to the tasks performed has resulted in various categories of skills in entrepreneurship. In an empirical study conducted on Jamaican instructors, a panel of experts grouped some of the competencies and skills into eight clusters which included team leadership, perception of trustworthiness, planning and organisation, basic business skills, communication, problem solving skills, personal traits and creativity (Dixon et al. 2005). The well-researched categories of skills presented in Table 2 are technical, business management, entrepreneurial, personal, social and interpersonal, and behavioural or motivational skills.

An entrepreneur engaged in innovation and production will require skills categorised as production skills. Then the category of production skills will be further divided into subcategories, which may include new ideas, new products and services skills. If the activity of the entrepreneurial phase has to deal with opportunity recognition, then an entrepreneur is required to possess special skills of identifying and choosing opportunities from a variety of available choices, thus opportunity recognition skills (Fletcher 2006).

Besides definitional issues in entrepreneurship skills research, another complexity is to differentiate entrepreneurial from management skills. Table 2 presents the six categories of skills derived from the literature, with management skills differentiated from entrepreneurial skills. As noted from the two schools of entrepreneurship, the discipline is founded on innovation or novelty (Schumpeter 1934) and opportunity recognition (Kirzner 1973). Shane and Venkataraman (2000) and Timmons (1999) agreed that opportunity recognition and exploitation are the fundamental constructs, which separate entrepreneurship from management. In the same vein Markman (2007) is of the notion that the core of entrepreneurial skills is opportunity recognition and exploitation. Therefore, opportunity recognition differentiates entrepreneurial skills from management skills.

Table 2 indicates that some of skills identified in literature are not actually skills, but they are more aligned with personality traits or qualities and behaviour. The lack of a proper definition

TABLE 1: Definition of skills.

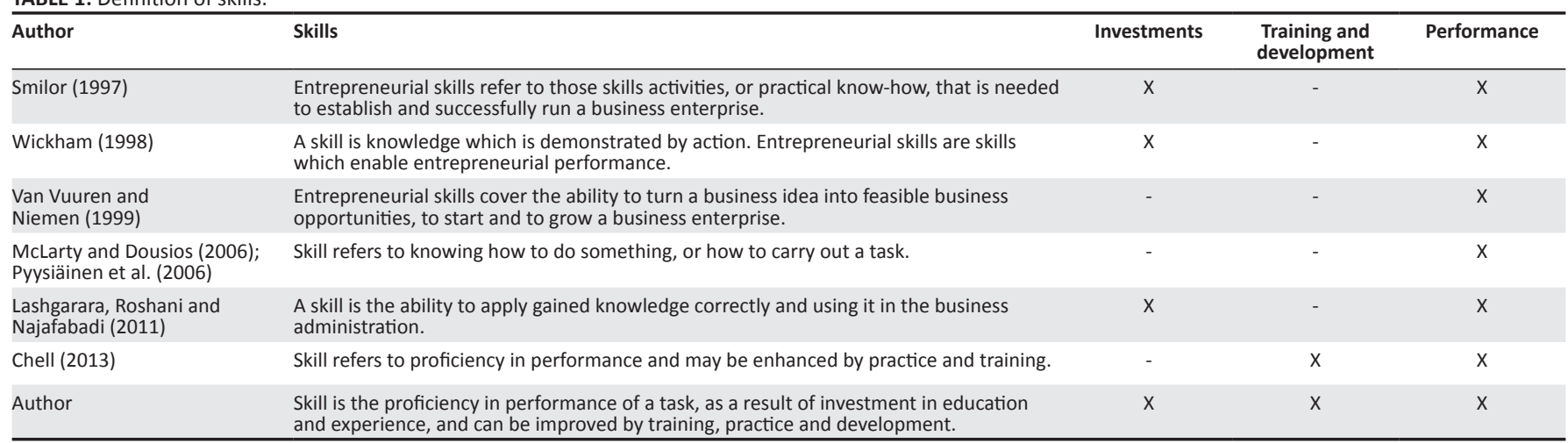

Source: Authors' own work 
TABLE 2: Skills categories and their sub-sets.

\begin{tabular}{|c|c|c|c|}
\hline Category of skills & Operation definition & Subset of skills & Authors \\
\hline Technical skills & Performing key operations of the business & $\begin{array}{l}\text { Managing operations, managing supplies and supply chains, } \\
\text { production space skills, managing plant and equipment, } \\
\text { technology and production processes, management styles, } \uparrow \\
\text { written and oral communication and knowledge of } \\
\text { manufacturing technology } \dagger\end{array}$ & $\begin{array}{l}\text { Chang and Rieple (2013); Chell } \\
\text { (2013); Narkhede et al. (2014) }\end{array}$ \\
\hline $\begin{array}{l}\text { Business } \\
\text { management skills }\end{array}$ & $\begin{array}{l}\text { Organising and effectively managing the operations of } \\
\text { the business (Lichtenstein \& Lyons 2001) }\end{array}$ & $\begin{array}{l}\text { Planning, organising, supervising, marketing skills, financial } \\
\text { management skills, legal skills, administrative skills, high order } \\
\text { skills related to learning and problem solving, marketing, } \\
\text { human resource management, marketing, networking, } \\
\text { operational skills, business planning skills and negotiation skills }\end{array}$ & $\begin{array}{l}\text { Botha, Nieman and van Vuuren } \\
\text { (2006); Hisrich, Peters and } \\
\text { Shepherd (2005); Loué and } \\
\text { Baronet (2012) }\end{array}$ \\
\hline Entrepreneurial skills & $\begin{array}{l}\text { Birth, growth and performance of a business } \\
\text { enterprise. These are skills needed to develop } \\
\text { innovative products and services and to generate } \\
\text { solutions to emerging needs in the marketplace }\end{array}$ & $\begin{array}{l}\text { Ability to develop business concepts and a business plan, } \\
\text { environmental scanning, opportunity recognition, } \dagger \text { advisory } \\
\text { board and networking, innovation, new resource skills, } \\
\text { calculated risk } \dagger \text { or risk propensity, change orientation, visionary } \\
\text { leadership, } \dagger \text { inner control, } \dagger \text { creativity } \dagger \text { and persistence } \dagger\end{array}$ & Shane (2000); Timmons (1999) \\
\hline Personal skills & $\begin{array}{l}\text { Skills which are needed to attain self-awareness, } \\
\text { emotional maturity, ability and willingness to accept } \\
\text { responsibility }\end{array}$ & $\begin{array}{l}\text { Self-awareness, } \dagger \text { accountability, } \uparrow \text { emotional coping, } \dagger \text { creativity, } \\
\text { change orientation, } \dagger \text { motivation, } \dagger \text { negotiating skills, learning } \\
\text { skills, communication skills and self-efficacy } \dagger\end{array}$ & $\begin{array}{l}\text { Chang and Ripple (2013); Narkhede } \\
\text { et al. (2014); Timmons and Spinelli } \\
\text { (2004) }\end{array}$ \\
\hline $\begin{array}{l}\text { Behavioural and } \\
\text { motivational skills }\end{array}$ & $\begin{array}{l}\text { Skills which are associated with a behaviour and desire } \\
\text { to achieve }\end{array}$ & 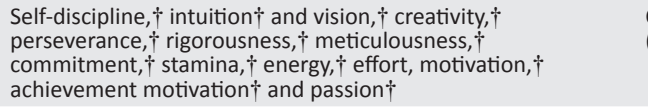 & $\begin{array}{l}\text { Chell (2013); Loué and Baronet } \\
\text { (2012) }\end{array}$ \\
\hline $\begin{array}{l}\text { Social and } \\
\text { interpersonal skills }\end{array}$ & $\begin{array}{l}\text { These are learnable behaviour used by individuals in } \\
\text { their interactions with others }\end{array}$ & $\begin{array}{l}\text { Persuasiveness, } \dagger \text { social skill, self-confidence, } \uparrow \text { trust } \\
\text { overconfidence, } \uparrow \text { leadership, } \uparrow \text { networking skills, self-efficacy, } \uparrow \\
\text { impression management, social adaptability, social perception, } \\
\text { self-promotion, expressiveness, perception and social influence }\end{array}$ & $\begin{array}{l}\text { Baron and Markman (2000); Baron } \\
\text { and Tang (2009); Chell (2013); } \\
\text { Morales and Marquina (2013) }\end{array}$ \\
\hline
\end{tabular}

$\dagger$, This element is more of behaviour or trait rather than skill according to skills definition in this study.

Source: Authors' own work

of skills resulted in many skills definitions, characteristics, variables and attributes in the literature appearing to be unclear. For example, risk propensity which is known as an entrepreneurial trait or personality characteristic can be regarded as a skill (Chell 2013). This categorisation makes risk propensity to be regarded as multidimensional, thus having the properties of both a trait and skill.

Baum, Locke and Smith (2001) highlighted that entrepreneurial personality traits may serve to influence skills sets which are developed. In addition, entrepreneurial personality traits such as self-efficacy, passion, visionary and tenacity may influence the individual's ability to perform entrepreneurial activities and ultimately impact on the business venture growth. Noting this challenge, it is therefore significant to treat personality characteristics or traits and skills as separate entities. However, the entrepreneurship literature does not offer much distinction between the two constructs.

\section{Research design and methodology}

The research question that this study intended to answer is: what are the skills needed by entrepreneurs to run their businesses on day-to-day basis?

\section{Main research objective}

The main objective was to determine the clusters, categories and sub-skills applied by entrepreneurs when running their businesses.

\section{Research design}

The design choice for this study was a mixed method approach. The mixed method originated as triangulation, which is the combination of qualitative and quantitative methodologies in the study of the same phenomenon
(Denzin 1978; Jick 1979). The strategy followed in this study is one of sequential exploratory research whereby qualitative interviews were conducted in Phase I followed by a quantitative survey in Phase II (Creswell 2009).

\section{Phase I (qualitative) design and method}

The qualitative interviews were conducted in Phase I to identify skills and use the results of the qualitative phase to develop a survey instrument for measuring skills against a larger population of entrepreneurs. The data were collected through face-to-face interviews with a purposive sample of 15 entrepreneurs and 6 national experts in entrepreneurship. After collecting the qualitative data, the analysis was conducted by using ATLAS.ti, which is a computer-assisted qualitative data analysis software.

The analysis of the data occurred in series of steps whereby the first step was to develop a code book of skills, which included categories of skills, their sub-skills and operational terms. After all the interviews were transcribed, the next step was to closely appraise the data. This step involved reading through all the data to obtain a general sense of the information and to reflect on its overall meaning (Creswell 2003). Coding is the process of organising the data into chunks or segments of text before bringing meaning to information (Creswell 2003). ATLAS.ti was used to code, organise, compare different codes and sort the significant data that were best in describing the qualitative findings. The last step involved revising and refining the developed skills categories. The data analysis resulted in the categories of skills and their sub-sets, which were used to develop a questionnaire.

\section{Phase II (quantitative) design and method}

In Phase II, the quantitative study was aimed at confirming the skills and the sub-skills that were derived from the qualitative phase. The sample frame for the quantitative 
study was a list of South African entrepreneurs in all nine provinces, which are as follows: Gauteng, Northern Cape, Western Cape, Eastern Cape, Free State, Mpumalanga, Limpopo, KwaZulu-Natal and North West. After data collection by using an online survey, there were 235 entrepreneurs who participated in the study.

The skills that were derived in the qualitative phase were confirmed through confirmatory factor analysis (CFA). This analysis is a way of testing how well the measured items represent a smaller number of constructs. This method was appropriate to test the extent to which the proposed sub-skills pattern of the factor loadings on the pre-specified skills constructs represent the actual data (Hair et al. 2010). The models were evaluated for fit in terms of significance and the strength of the parameters, as well as how well the overall model fits the observed data, as indicated by a variety of fit indices. The chi-square and the goodness-of-fit index (GFI), comparative fit index (CFI), Tucker-Lewis index (TLI), normed fit index (NFI) and root-mean square residual (RMSEA) indices were used to determine the model fit (Kline 2011).

Through CFA, the categories of skills developed were startup skills, core business skills (business management, financial management, human resource management and marketing skills), personal and leadership skills (social and interpersonal, leadership and personal skills) and technical skills. In this study, the focus was on skills at a given point in time, thus adopting a cross-sectional study as the time horizon (Saunders, Lewis \& Thornhill 2009).

\section{Research findings Qualitative phase results}

Table 3 shows the final skills clusters, categories, sub-skills and their operational definitions. The identified skills were

TABLE 3: Qualitative findings of skills and their sub-categories.

\begin{tabular}{|c|c|c|c|}
\hline Cluster & Category & Sub-skill & Operational definition \\
\hline \multirow[t]{9}{*}{ Start-up skills } & \multirow[t]{9}{*}{ Start-up skills } & Prototyping & Testing the feasibility of the business idea \\
\hline & & Starting up a venture & Gathering material and financial resources to start a new venture \\
\hline & & Formalising business plan & Developing a business model or plan to run the business \\
\hline & & Growth planning & Planning the growth of the business in short and long term \\
\hline & & Assess own capabilities & Showing compelling drive to achieve the set objectives \\
\hline & & Environmental scanning & Scanning trends outside the environment of business \\
\hline & & Innovation & Developing new ideas, products and envision possibilities \\
\hline & & Calculated risk & Taking calculated risks to run the business \\
\hline & & Opportunity recognition & Identifying business opportunities \\
\hline \multirow{11}{*}{$\begin{array}{l}\text { Core business } \\
\text { skills }\end{array}$} & \multirow{11}{*}{$\begin{array}{l}\text { Business management } \\
\text { skills }\end{array}$} & Problem solving & Identifying and solving problems encountered in the business \\
\hline & & Strategic competence & Identifying where the business is and where it needs to go \\
\hline & & Legal skills & Complying with the law and regulations set by government \\
\hline & & Planning & Planning the activities in the business \\
\hline & & Negotiation & Negotiating to obtain better business deals \\
\hline & & Decision-making & Making decisions in running the business \\
\hline & & Delegation & Delegating tasks to employees \\
\hline & & Distribution model & Making the product available in the market \\
\hline & & Managing change & Managing the changes in the business \\
\hline & & Partnerships & Attracting investors and potential partners \\
\hline & & Business development & Developing or growing the business by diversification \\
\hline \multirow[t]{8}{*}{ Core business skills } & \multirow[t]{8}{*}{ Marketing skills } & Market research & Conducting market research \\
\hline & & Monitoring competitors & Monitoring and benchmarking the competition \\
\hline & & Positioning & Finding the market position in which the business operates \\
\hline & & Selling & Selling the product, either tangible or intangible \\
\hline & & Advertising the business & Seeking out new clients, e.g. at trade shows or exhibitions \\
\hline & & Branding & Creating a positive brand or image of the business \\
\hline & & Customer experience & Creating good customer experience and loyalty \\
\hline & & Social media marketing & Using social media to advertise the business \\
\hline \multirow{9}{*}{ Core business skills } & \multirow{9}{*}{ Financial management skills } & Raising capital & Gathering financial resources to start or to grow the business \\
\hline & & Managing cash & Managing the money transferred in and out of the business \\
\hline & & Calculating costs & Calculating costs, cost prices and the margins \\
\hline & & Interpreting financial results & Reading and analysing balance sheet and income statement \\
\hline & & Filing up tax reports & Filing up tax returns with the revenuer services \\
\hline & & Using financial software & Using financial software to produce financial reports \\
\hline & & Managing billing & Managing invoicing and collecting payments from clients \\
\hline & & Book keeping & Understanding and interpreting the financial records \\
\hline & & Selling or buying shares & $\begin{array}{l}\text { Selling a certain portion of the company shares in exchange for money to grow the } \\
\text { business }\end{array}$ \\
\hline
\end{tabular}


TABLE 3: (Continued...) Qualitative findings of skills and their sub-categories

\begin{tabular}{|c|c|c|c|}
\hline Cluster & Category & Sub-skill & Operational definition \\
\hline \multirow[t]{8}{*}{ Core business skills } & \multirow{8}{*}{$\begin{array}{l}\text { Human resource } \\
\text { management skills }\end{array}$} & Recruitment & Recruiting and employing right people for the job \\
\hline & & Developing employees & Evaluating if the employees have the right skills to perform the tasks \\
\hline & & Evaluating employees' skills & Assessing the overall performance of employees \\
\hline & & Evaluating performance & Evaluating and overseeing employee's potential and career \\
\hline & & Setting roles & Defining jobs in terms of activities and skills and drawing up job descriptions \\
\hline & & Paying salaries & Implementing pay policy by defining salaries and bonuses \\
\hline & & Dismissing employees & Terminating employee contracts while respecting employment law \\
\hline & & $\begin{array}{l}\text { Using human resource } \\
\text { technologies }\end{array}$ & Using software to manage human resource matters \\
\hline \multirow[t]{6}{*}{ Technical skills } & \multirow[t]{6}{*}{ Technical skills } & Industry-specific & Applying skills that are relevant in the industry \\
\hline & & Product development & Developing the product, either tangible or intangible \\
\hline & & Managing operations & Managing the production of the products or services \\
\hline & & Managing supplies & Distributing the products to the market \\
\hline & & Quality audit & Assessing if the product adheres to industry norms or standards \\
\hline & & Continuous innovation & Continuously innovating existing products or services \\
\hline \multirow[t]{12}{*}{ Personal and leadership skills } & \multirow[t]{12}{*}{ Personal skills } & Accountability & Focusing up on the intended goals or purpose \\
\hline & & Hard work & Going the extra mile and working long hours \\
\hline & & Intuition & Following your gut feeling when making decisions \\
\hline & & Passion & Enthusiastic about starting and running a business \\
\hline & & Self-motivation & $\begin{array}{l}\text { Encouraging yourself and relying on the inward strength in executing entrepreneurial } \\
\text { activities }\end{array}$ \\
\hline & & Single mindedness & Sticking with something even when the going gets tough \\
\hline & & Tenacity & Enduring in hard situations \\
\hline & & Time management & Scheduling and executing activities according the allocated time \\
\hline & & Assertiveness & Saying no to business deals without being too desperate \\
\hline & & Emotional coping & Dealing with stressful situations \\
\hline & & Learning ability & Learning in difficult challenges \\
\hline & & Creativity & Initiating new things in the business \\
\hline \multirow{4}{*}{ Personal and leadership skills } & \multirow{4}{*}{ Leadership skills } & Sharing vision & Sharing the vision of the company with the employees \\
\hline & & Culture of performance & Encouraging employees to have excellent performance \\
\hline & & Thought leadership & Establishing oneself as the leader in the industry \\
\hline & & Leading responsibly & Leading with responsibly and ethical manner \\
\hline \multirow[t]{7}{*}{ Personal and leadership skills } & \multirow[t]{7}{*}{ Social and interpersonal skills } & People skills & Showing sensitivity to people's feelings and emotions \\
\hline & & Communication skills & Communicating meaningfully with employees, customers and other stakeholders \\
\hline & & Building relationships & Building relationships of trust with clients \\
\hline & & Understanding cultures & Working well with people of different cultures \\
\hline & & Political astuteness & Identifying and overcoming the political challenges \\
\hline & & Networking & Networking to build resources and opportunities \\
\hline & & Listening & Listening to and hearing what other people are saying \\
\hline
\end{tabular}

Source: Authors' own work

used to develop the survey instrument for data collection in Phase II.

\section{Reliability and validity of qualitative findings}

Reliability of the data was ensured by minimising the respondents' bias. The respondents were assured of anonymity in the data collection process, analysis and reporting of the findings (Saunders et al. 2009). The transcripts were examined to remove some notable mistakes that were committed during the process of transcription and assure that the interview data are accurately represented. In cases where recorded data were found to be unclear, participants were contacted again for further clarifications and confirmations. During the coding process, the consistency of definitions and meanings of the codes as guided by the code book was maintained.
In order to validate the qualitative findings, the use of experts in the field of entrepreneurship and research methodology who gave guidance on the research also helped to lend depth of legitimacy to the process. After the analysis of the data, the findings of the study were verified by presenting them to some of the entrepreneurs who participated in the qualitative interviews. Finally, the clusters of the skills were compared with the literature findings.

\section{Quantitative phase results}

\section{Skills categories}

The categories that were derived from CFA are shown in Table 4. GFI and CFI values of the categories were above the good fit value which is 0.90 . RMSEA for most of the categories were within the good fit range of 0.05-0.08; however, for the financial management skills were slightly below while the 
TABLE 4: Confirmatory factor analysis.

\begin{tabular}{|c|c|c|c|c|c|}
\hline Skills & Chi-square & $\mathrm{GFI}>0.90$ & $\mathrm{CFI}>0.90$ & RMSEA 0.05-0.08 & Cronbach's alpha $>0.70$ \\
\hline Start-up (entrepreneurial) & 2.8 & 0.995 & 0.998 & 0.042 & 0.800 \\
\hline Business management & 39.6 & 0.961 & 0.967 & 0.075 & 0.838 \\
\hline Financial management & 0.3 & 0.999 & 1.000 & 0.000 & 0.773 \\
\hline Marketing & 1.2 & 0.997 & 0.998 & 0.027 & 0.764 \\
\hline Human resource management & 6.4 & 0.990 & 0.994 & 0.069 & 0.872 \\
\hline Technical & 0.2 & 1.000 & 1.000 & 0.000 & 0.872 \\
\hline Social and interpersonal & 4.9 & 0.992 & 0.987 & 0.052 & 0.842 \\
\hline Leadership & 5.7 & 0.990 & 0.992 & 0.089 & 0.819 \\
\hline Personal & 0.0 & 1.000 & 1.000 & 0.000 & 0.842 \\
\hline Core business cluster & 221.9 & 0.905 & 0.945 & 0.058 & 0.874 \\
\hline Personal and leadership cluster & 56.3 & 0.958 & 0.983 & 0.045 & 0.860 \\
\hline
\end{tabular}

Source: Authors' own work

leadership skills were slightly above the values of a good fit. The Cronbach's alpha of each category of skills was above 0.70 , indicating that the internal consistency was very good (Kline 2011).

\section{Skills clusters}

In the second level analysis, some of the categories of skills were clustered together. CFA was run to determine if the clusters were significant. The main clusters of the skills are start-up, personal and leadership, core business and technical skills. The start-up and technical skills were not part of any cluster, therefore remained as standalones.

Start-up skills: The initial computation of the model had a chi-square $=34.1, d f=5, \mathrm{GFI}=0.946$ and $\mathrm{CFI}=0.917$ and RMSEA $=0.158$. Because the RMSEA results were higher than the expected value, the modification indices were examined to check if the model could be improved. The covariates of planning growth, environmental scanning, calculated risks and opportunity recognition were found to be highly related. After correlating the covariates, the model improved with a chi-square $=2.8, d f=2$, RMSEA $=0.042, \mathrm{CFI}=0.998$ and GFI $=$ 0.995. The reliability test of the factors had a Cronbach's alpha of 0.80 , indicating that the items measured what the instrument intended to measure. The results indicated that all the variables including planning growth, environmental scanning, new idea generation, taking calculated risks and opportunity recognition had a high loading on start-up skills construct.

Technical skills: The first model that was computed was a poor fit with chi-square $=124.9, d f=9, \mathrm{GFI}=0.858$, $\mathrm{CFI}=0.798$ and RMSEA $=0.234$. The modification indices showed that using specialised technology and continuous innovation had low factor loadings, and as a result, they were removed. After correlating the covariates of product development and quality evaluation the global fit indices improved to chi-square $=0.2, d f=1, \mathrm{GFI}=1.00, \mathrm{CFI}=1.00$ and RMSEA $=0.000$. The reliability analysis of the final factors had a Cronbach's alpha of 0.850 , which is above the expected. Therefore, the measurement items or factors for the technical skills are industry-specific skills, product development, managing production and product quality evaluation.
Core business cluster: The first computation of the model showed that the data on business management, human resource management, marketing and financial management skills which were grouped together did not fit the model. The initial results had a chi-square $=413.0, d f=178, \mathrm{GFI}=0.852, \mathrm{CFI}=0.892$ and RMSEA $=0.075$. In order to obtain a good fit, factors with the cross-loading variables were removed negotiation, decisionmaking and positioning the business to ensure discriminant validity. After model trimming there was an improvement of the global model fit indices to chi-square $=221.9, d f=124, \mathrm{GFI}=$ $0.905, \mathrm{CFI} 0.945, \mathrm{TLI}=0.932$ and RMSEA $=0.058$. The reliability analysis was run on the measurement items and the results showed a Cronbach's alpha of 0.874 for the 18 items in the core business skills cluster. Therefore, the core business skills cluster consists of financial management, human resource management, marketing and business management skills.

Personal and leadership cluster: The social and interpersonal, personality and leadership skills were brought together to form a cluster of personal and leadership skills. The first model that was computed with the three categories (social and interpersonal, personality and leadership) of skills almost met the good fit criteria with chi-square $=180.7, d f=57, \mathrm{CFI}=0.910$, RMSEA $=0.096$ except for GFI $=0.897$. The modification indices showed that L1 (crafting a vision) and LS6 (leading responsibly) had poor loadings, and as a result they were removed from the analysis. The model trimming improved the global fit indicators to chi-square $=56.3, d f=38, \mathrm{GFI}=0.958, \mathrm{CFI}=$ 0.983 , TLI $=0.975$ and RMSEA of 0.045 . The reliability tests of personality and leadership skills cluster had a Cronbach's alpha of 0.860 . Therefore, based on the results presented above, social and interpersonal, personality and leadership skills form a cluster of personality and leadership skills. The skills codes in the diagram are presented in Table 5. Table 5 shows the summary of skills clusters, categories and subskills that were derived from CFA.

\section{Discussion}

The study commenced by identifying the skills applied by entrepreneurs in running their businesses. As a result, nine categories of skills were identified from the qualitative data analysis and were validated in the quantitative phase through CFA. 
TABLE 5: Summary of skills from quantitative phase.

\begin{tabular}{ll}
\hline Skills clusters & Skills categories and their sub-skills \\
\hline Start-up skills & Start-up: growth planning, environmental scanning, innovation, calculated risk taking and opportunity recognition \\
Core business skills & Business management: planning, problem solving, business modelling, legal skill, decision-making, delegation, business development and strategic competence \\
& Marketing: market researching, benchmarking competition, business positioning and selling \\
& Financial management: pricing products, cash flow management, calculating costs and reading financial statements \\
& Human resource management: recruitment, employees skills assessment, defining job specs, performance management and payment of salaries \\
Technical skills & Technical: industry-specific skills, product development, managing operations and quality audit \\
Personal and & Leadership: crafting vision, inspiring employees, sharing the vision, cultivating excellent performance and leading responsibly \\
leadership skills & Social and interpersonal: people skills, communication, listening, building relationships and cultural sensitivity \\
& Personal: hard work, intuition in decision-making and self-motivation \\
\hline
\end{tabular}

Source: Authors' own work

Start-up skills are necessary for the identification and exploitation of a business opportunity. Consistent with the literature these can also be termed 'entrepreneurial or opportunity recognition skills' (Loué \& Baronet 2012; Wasdani \& Mathew 2014). The start-up skills include opportunity recognition and exploitation, calculated risk taking, innovation, environmental scanning and planning the growth of the business.

Technical skills include an understanding of and proficiency in specific activities involving methods, processes and techniques in the business's line of operation. The technical skills include industry-specific skills, product development, management of operations and quality-monitoring skills.

Core business skills focus on the internal business environment, which involves financial management, human resource management and technical skills:

- Business management skills are needed to run the business on a daily basis. The business management skills that were considered significant were planning, problem solving, legal skills, decision-making, developing and executing a business model, strategic competence, delegation and business development.

- Financial management skills are required to manage capital in an efficient and effective way so as to accomplish the financial obligations of the business. The financial management skills were pricing products (tangible or service), cash flow management, calculating costs and interpreting financial statements.

- Marketing skills are about communicating the value of the tangible and service products to the customers, for the purpose of selling. Therefore, skills under the marketing category are market research, benchmarking competition, positioning the business in the market and selling skills.

- Human resource management skills pertain to the ability to deal with managing people in the business, including designing and implementing workplace policies. The skills under this category were recruitment, employees' skills assessment, defining job specs, performance management and payment of salaries.

Personal and leadership skills focus on leading employees to achieve maximum results and interaction with stakeholders. The stakeholders can either be internal, for instance employees or external such as customers and suppliers.
The categories of skills within this cluster were social and interpersonal, leadership and personal skills:

- Social and interpersonal skills: In order to interact and form relationships with other people, entrepreneurs need social and interpersonal skills. The significant skills in this category are: people skills, communication skills, listening, building relationships and cultural sensitivity.

- Leadership skills are needed to lead 'self' and employees in the business. The sub-skills within this category include crafting vision, inspiring employees, sharing the vision, cultivating excellent performance and leading responsibly.

- Personal skills: The skills under this category are hard work, intuition and self-motivation.

The four main clusters of skills derived from this study were consistent with Chandler and Jansen (1992), Man and Lau (2000), Loué and Baronet (2012) and Chell (2013). However, the identified clusters had more categories and sub-skills than those already existing in the literature. Also, Pyysiäinen et al. (2006) noted that there is scarcity of exhaustive list of skills that match the different functional areas in the business. Pyysiäinen et al. (2006) argued that skills should be related to the different functions of the business. In each functional area there are activities that need to be performed and those activities have requisite skills. Therefore, this study addressed the categories and their sub-sets of skills, which deal with the functional areas such as marketing, finance, human resource, business management and technical functions.

Besides the skills specific to the functional business areas, there were skills which differentiate entrepreneurs from nonentrepreneurs and these were start-up skills (Carland et al. 1984). In addition to start-up skills, there were personal and leadership skills, which can be seen as 'soft skills' pertaining to the entrepreneur's relations and engagements with stakeholders.

There were inconsistencies within the identification of subskills in the personal skills category. Some of the sub-skills identified in the qualitative phase did not load well on the personal skills construct in CFA. The skills which did not load well were assertiveness, passion, single mindedness, emotional coping and accountability. An explanation to this may be that these skills are assumed to be behaviours or personal traits (Rauch \& Frese 2007), and as a result they will load better when classified with other personality traits. Baum et al. (2001) separated skills from traits by empirically 
showing that personality traits may serve to impact the development of skills for running a business. Therefore, this study supports the notion that skills should be considered as being different from traits.

\section{Conclusions and practical implications}

Using both qualitative and quantitative methods this study was able to identify an exhaustive list of skills with operational definitions. The entrepreneurship management skills needed by entrepreneurs are financial management, human resource management, start-up, social and interpersonal, leadership, personality, marketing, technical and business management skills. These categories of skills were found to be consistent with the existing literature but were more exhaustive and included new skills not identified in prior literature. Based on the empirical findings presented in the previous sections, this study makes some recommendations. Firstly, the identified skills can be used as a questionnaire for empirical testing in an attempt to advance theory on entrepreneurship. Secondly, the skills framework can serve as a baseline for skills training, support, mentoring and development programmes to develop practical and critical skills required in the process of entrepreneurship - what cannot be identified, cannot be developed. If entrepreneurship education and training based on the identified skills are implemented, even in a weaker overall educational system, the level of entrepreneurship activity can be improved. Finally, for the enterprise development programme, the skills framework can be adapted into a skills tool which can be used for pre- and posttraining assessment of skills. This will assist in determining the skills needs of entrepreneurs before the training and in accessing impact of training on skills development of entrepreneurs.

\section{Limitations and future research}

Although the categories and skills of clusters may be generalisable in a different contextual setting, a probable limitation is that the sub-sets of the skills may not all be generalisable in a different context of application. The research was positioned in a context, which is characterised by a low entrepreneurial activity and low skills levels; therefore, the study may be less generalisable in contexts where entrepreneurial activity and skills are very high. The empirical evidence of the impact of skills on venture outcomes remains unknown as this study did not have an outcome variable of skills.

Because this was a cross-sectional study, future research can focus on how skills change over time as the entrepreneurship process unfold with a focus on entrepreneurs at different phases. Also, a deeper investigation into the sources of entrepreneurial skills and determine the informal platforms from which entrepreneurs learn skills. The study did not focus on entrepreneurial tasks and their requisite skills, so future studies can discover the requisite skills required to perform those activities. Future research should also test the generalisability of the skills framework in a different contextual setting and to a larger population.

\section{Acknowledgements}

Thanks to the Gordon Institute of Business Science (GIBS) and National Research Foundation (NRF) for the financial support.

\section{Competing interests}

The authors declare that they have no financial or personal relationships which may have inappropriately influenced them in writing this article.

\section{Authors' contributions}

M.A.M. conducted the research study, literature review and wrote the first draft of the article. M.K. and T.K. contributed in the conceptualisation of the theoretical framework and interpretation of the research findings.

\section{References}

Adendorff, C., Emuze, F. \& Vilakazi, E., 2013, 'Evaluating the skills of emerging entrepreneurs in a developing economy', International Journal of Socia Entrepreneurship and Innovation 2(3), 240-252. https://doi.org/10.1504/IJSEI. 2013.057019

Ahmad, N.H., Ramayah, T., Wilson, C. \& Kummerow, L., 2010, 'Is entrepreneurial competency and business success relationship contingent upon business environment? A study of Malaysian SMEs', International Journal of Entrepreneurial Behaviour \& Research 16(3), 182-203. https://doi.org/10.1108/13552551011042780

Amorós, J.E. \& Bosma, N., 2014, Global entrepreneurship monitor 2013 global report, Global Entrepreneurship Research Association, London, United Kingdom.

Baron, R.A. \& Markman, G.D., 2000, 'Beyond social capital: How social skills can enhance entrepreneurs' success', The Academy of Management Executive 14(1), 106-116. https://doi.org/10.5465/ame.2000.2909843

Baron, R. A., \& Tang, J., 2009, "Entrepreneurs" social skills and new venture performance: Mediating mechanisms and cultural generality', Journal of Management 35(2), 282-306.

Baum, J.R., Locke, E.A. \& Smith, K.G., 2001, 'A multidimensional model of venture growth', Academy of Management Journal 44(2), 292-303. https://doi.org/10. 2307/3069456

Becker, G.S., 1964, Human capital: A theoretical and empirical analysis, with special reference to education, National Bureau of Economic Research, New York.

Bird, B., 1995, 'Towards a theory of entrepreneurial competency', Advances in Entrepreneurship Firm Emergence and Growth 2(1), 51-72.

Botha, M., Nieman, G. \& van Vuuren, J., 2006, 'Enhancing female entrepreneurship by enabling access to skills', The International Entrepreneurship and Management Journal 2(4), 479-493. https://doi.org/10.1007/s11365-006-0011-2

Boyatzis, R.E., 1982, The competent manager: A model for effective performance (Bound), Wiley, New York.

Brière, S., Tremblay, M. \& Daou, A., 2014, 'Entrepreneurship in South Africa: Looking beyond funding', Development and Learning in Organizations 28(2), 17-19. https://doi.org/10.1108/dlo-08-2013-0052

Bruton, G.D., Ahlstrom, D. \& Obloj, K., 2008, 'Entrepreneurship in emerging economies: Where are we today and where should the research go in the future', Entrepreneurship Theory and Practice 32(1), 1-14. https://doi.org/10.1111/j. 1540-6520.2007.00213.x

Carland, J.W., Hoy, F., Boulton, W.R. \& Carland, J.A.C., 1984, 'Differentiating entrepreneurs from small business owners: A conceptualization', Academy of Management Review 9(2), 354-359.

Chandler, G.N. \& Jansen, E., 1992, 'The founder's self-assessed competence and venture performance', Journal of Business Venturing 7(3), 223-236. https://doi. org/10.1016/0883-9026(92)90028-P

Chang, J. \& Rieple, A., 2013, 'Assessing students' entrepreneurial skills development in live projects', Journal of Small Business and Enterprise Development 20(1) 225-242. https://doi.org/10.1108/14626001311298501

Chell, E., 2013, 'Review of skill and the entrepreneurial process', International Journal of Entrepreneurial Behaviour \& Research 19(1), 6-31. https://doi.org/10.1108/ 13552551311299233

Creswell, J.W., 2003, Research design: Qualitative, quantitative, and mixed methods approaches, Sage, London, United Kingdom. 
Creswell, J.W., 2009, Research design: Qualitative, quantitative, and mixed methods approaches, Sage, London, United Kingdom.

Deakins, D., Bensemann, J. \& Battisti, M., 2016, 'Entrepreneurial skill and regulation: Evidence from primary sector rural entrepreneurs', International Journal of Entrepreneurial Behavior \& Research 22(2), 234-259. https://doi.org/10.1108/ IJEBR-12-2014-0240

Denzin, N.K., 1978, The research act, 2th edn., McGraw-Hill, New York.

Dixon, R., Meier, R.L., Brown, D.C. \& Custer, R.L., 2005, 'The critical entrepreneurial competencies required by instructors from institution-based enterprises: A Jamaican study', Journal of Industrial Teacher Education 4(42), 25-51.

Fletcher, D.E., 2006, 'Entrepreneurial processes and the social construction of opportunity', Entrepreneurship and Regional Development 18(5), 421-440. https://doi.org/10.1080/08985620600861105

Hair, J.F., Black, W.C., Babin, B.J., Anderson, R.E. \& Tatham, R.L., 2010, Multivariate data analysis, 7th edn., Pearson Prentice Hall, Upper Saddle River, NJ.

Hayton, J.C. \& McEvoy, G.M., 2006, 'Competencies in practice: An interview with Hanneke C. Frese', Human Resource Management 45(3), 495-500. https://doi. org $/ 10.1002 / \mathrm{hrm} .20126$

Herrington, M. \& Kew, P., 2015, GEM 2015-2016 South Africa report, Global Entrepreneurship Research Association, Cape Town.

Herrington, M., Kew, J. \& Kew, P., 2014, GEM 2014 sub-Saharan Africa report, Global Entrepreneurship Research Association, Cape Town.

Hisrich, R.D., Peters, M.P. \& Shepherd, D.A., 2005, Entrepreneurship, 6th edn. McGraw-Hill, New York.

Jick, T.D., 1979, 'Mixing qualitative and quantitative methods: Triangulation in action', Administrative Science Quarterly 24(4), 602-611. https://doi.org/10.2307/2392366

Kirzner, I.M., 1973, Competition and entrepreneurship, University of Chicago Press, Chicago, IL.

Kline, R.B., 2011, Principles and practice of structural equation modeling, Guilford Press, New York.

Lashgarara, F., Roshani, N. \& Najafabadi, M.O., 2011, 'Influencing factors on entrepreneurial skills of rural women in Ilam City, Iran', African Journal of Business Management 5(14), 5536-5540.

Lichtenstein, G.A. \& Lyons, T.S., 2001, 'The entrepreneurial development system: Transforming business talent and community economies', Economic Development Quarterly 15(1), 3-20. https://doi.org/10.1177/089124240101500101

Loué, C. \& Baronet, J., 2012, 'Toward a new entrepreneurial skills and competencies framework: A qualitative and quantitative study', International Journal of Entrepreneurship and Small Business 17(4), 455-477. https://doi.org/10.1504/ IJESB.2012.050164

Lugemwa, P., 2014, 'Improving the secondary school curriculum to nurture entrepreneurial competences among students in Uganda', International Journal of Secondary Education 2(4), 73-86. https://doi.org/10.11648/j.ijsedu.20140204.13

Man, T.W. \& Lau, T., 2000, 'Entrepreneurial competencies of SME owner/manager in the Hong Kong service sector: A qualitative analysis', Journal of Enterprising Culture 8(03), 235-254. https://doi.org/10.1142/S0218495800000139

Markman, G.D., 2007, 'Entrepreneurs' competencies', in J.R. Baum, M. Frese \& R.A Baron (eds.), The psychology of entrepreneurship, pp. 67-92, Psychology Press, New York.

McLarty, R. \& Dousios, D., 2006, 'Dynamics and patterns of skills within small and medium-sized enterprises', Strategic Change 15(4), 175-186. https://doi.org/10. $1002 /$ jsc. 755
Mitchelmore, S. \& Rowley, J., 2010, 'Entrepreneurial competencies: A literature review and development agenda', International Journal of Entrepreneurial Behaviour \& Research 16(2), 92-111. https://doi.org/10.1108/13552551011026995

Morales, C. \& Marquina, P.S., 2013, 'Entrepreneurial skills, significant differences between Serbian and German entrepreneurs', The Business and Economics Research Journal 6(1), 129-141. https://doi.org/10.7835/jcc-berj-2013-0085

Narkhede, B.E., Nehete, R.S., Raut, R.D. \& Mahajan, S.K., 2014, 'Impact of entrepreneurial skills on the firm's performance: Evidence from manufacturing SMEs in India', International Journal of Indian Culture and Business Management 8(2), 216-236. https://doi.org/10.1504/IJICBM.2014.059207

Pyysiäinen, J., Anderson, A., McElwee, G. \& Vesala, K., 2006, 'Developing the entrepreneurial skills of farmers: Some myths explored', International Journal of Entrepreneurial Behaviour \& Research 12(1), 21-39. https://doi.org/10.1108/ 13552550610644463

Rauch, A. \& Frese, M., 2007, 'Let's put the person back into entrepreneurship research: A meta-analysis on the relationship between business owners' personality traits, business creation, and success', European Journal of Work and Organizational Psychology 16(4), 353-385. https://doi.org/10.1080/ 13594320701595438

Saunders, M., Lewis, P. \& Thornhill, A., 2009, Research methods for business students, 5th edn., Pearson Education, London.

Schumpeter, J.A., 1934, The schumpttr: Theory economic development, Harvard University Press, Boston, MA.

Shane, S., 2000, 'Prior knowledge and the discovery of entrepreneurial opportunities', Organization Science 11(4), 448-469. http://dx.doi.org/10.1287/orsc.11.4.448. 14602

Shane, S. \& Venkataraman, S., 2000, 'The promise of entrepreneurship as a field of research', Academy of Management Review 25(1), 217-226. https://doi.org/10. 5465/amr.2000.2791611

Smilor, R.W., 1997, 'Entrepreneurship: Reflections on a subversive activity', Journa of Business Venturing 12(5), 341-346. https://doi.org/10.1016/S0883-9026(97) 00008-6

Smith, B. \& Morse, E., 2005, Entrepreneurial competencies: Literature review and best practices, Small Business Policy Branch, Industry Canada, Ottawa, ON.

Solesvik, M., 2012, May, 'Entrepreneurial competencies in emerging economy context', paper presented at the 17th Nordic Conference on Small Business Research, Helsinki, 23-25 May. Timmons, J.A., 1999, New venture creation: Entrepreneurship for the 21st century, 5th edn., McGraw Hill, Irwin, PA.

Timmons, J.A. \& Spinelli, S., 2004, New venture creation: Entrepreneurship for the 21st century, 6th edn., Irwin, Boston, MA.

Turton, N. \& Herrington, M., 2012, Global entrepreneurship monitor 2012 South Africa, Global Entrepreneurship Research Association, Cape Town.

Unger, J.M., Rauch, A., Frese, M. \& Rosenbusch, N., 2011, 'Human capital and entrepreneurial success: A personal-analytical review', Journal of Business Venturing 26(3), 341-358. https://doi.org/10.1016/j.jbusvent.2009.09.004

Van Vuuren, J.J \& Nieman, G., 1999, 'Entrepreneurship education and training: A model for syllabi/curriculum development', paper presented at the 44th ICSB World Conference Proceedings, Italy, 20-23 June.

Wasdani, K.P. \& Mathew, M., 2014, 'Potential for opportunity recognition along the stages of entrepreneurship', Journal of Global Entrepreneurship Research 2(1), 7 . https://doi.org/10.1186/2251-7316-2-7

Wickham, P.A., 1998, Strategic entrepreneurship: A decision-making approach to new venture creation and management, Pitman, London. 